DOI: 10.12957/demetra.2017.25146

\title{
Concordance between equations for body weight estimation and their use in determining body mass index in hospitalized men and women
}

\section{Concordância entre equações para estimativa do peso corporal em homens e mulheres hospitalizados}

\author{
Lais Pessanha Leal ${ }^{1}$ \\ Marina Schmidt Mognhol' \\ Naira Marceli Fraga Silva ${ }^{2}$ \\ Glenda Blaser Petarli $i^{3}$ \\ Patrícia Moraes Ferreira Nunes ${ }^{4}$ \\ Valdete Regina Guandalinil \\ ${ }^{1}$ Universidade Federal do Espírito Santo, \\ Departamento de Educação Integrada em Saúde, \\ Curso de Nutrição. Vitória-ES, Brasil. \\ ${ }^{2}$ Hospital de Câncer de Barretos - Fundação Pio \\ XII. Barretos-SP, Brasil. \\ ${ }^{3}$ Hospital Cassiano Antonio Moraes, Unidade de \\ Nutrição Clínica. Vitória-ES, Brasil. \\ ${ }^{4}$ Universidade Federal do Espírito Santo, Centro \\ de Ciências da Saúde. Vitória-ES, Brasil. \\ Correspondence / Correspondência \\ Valdete Regina Guandalini \\ E-mail:valguandalini@gmail.com
}

\begin{abstract}
Introduction: Hospitalized patients require alternative nutritional assessment methods. Objective: To evaluate the concordance between predictive equations for body weight estimation and their use in determining body mass index in hospitalized men and women. Methods: This was a cross-sectional study in the university hospital. Estimated weight was calculated by using the predictive equations proposed by Chumlea et al., 1988 and Rabito et al., 2006. Actual nutritional diagnosis was obtained through the body mass index determined from the actual weight and the estimated weight. The agreement between the measurements was assessed by the intraclass correlation coefficient and the Bland Altman analysis. It adopted the significance level of $\mathrm{p}<0.05$. Results: There were differences in women between the actual weight and the weight estimated with the equation by Chumlea et al. $(p=0.00)$; the same differences were found between actual body mass index and estimated body mass index $(p=0.00)$. The linear regression coefficient between actual weight and estimated weight, as calculated with the equation by the Rabito et al., was $0.44(\mathrm{p}=0.00)$ in men and $0.18(\mathrm{p}=0.03)$ in women. Similar results were found between the actual body mass index and the weight estimated with the equation by Rabito et al. in women $(0.19 ; \mathrm{p}=0.02)$. There was excellent agreement between the actual weight and the estimated weight, and in the determination of body mass index. Conclusion: The weights calculated with the predictive equations compared to the actual weights show excellent agreement and low variability; the same is true for body mass index, hence indicating the use of both equations as an alternative, when real measurement is not possible.
\end{abstract}


Keywords: Body Weight. Body Mass Index. Estimation Techniques. Inpatients.

\section{Resumo}

Introdução: Pacientes hospitalizados necessitam de métodos alternativos para avaliação nutricional. Objetivo: Avaliar a concordância entre equações para estimativa do peso corporal e o uso das mesmas na determinação no índice de massa corporal em homens e mulheres hospitalizados. Métodos: Estudo transversal realizado em um hospital universitário. O peso estimado foi calculado a partir das equações de Chumlea et al., 1988, e Rabito et al., 2006. O índice de massa corporal foi determinado pelo peso real e pelos estimados. A concordância entre as medidas foi avaliada pelo coeficiente de correlação intraclasse e pela análise de Bland Altman. Adotou-se o nível de significância de p <0,05. Resultados: Foram identificadas diferenças nas mulheres entre as diferenças do peso real e o estimado pela equação de Chumlea et al. $(p=0,00)$, o mesmo observado entre as diferenças do índice de massa corporal atual e o estimado $(\mathrm{p}=0,00)$. O coeficiente de correção linear entre peso atual e o estimado por Rabito et al. foi de $0,44(p=0,00)$ em homens e $0,18(p=0.03)$ em mulheres. Resultados similares foram obtidos entre o índice de massa corporal atual e o estimado em mulheres $(0,19 ; \mathrm{p}=0,02)$. Excelente concordância foi apresentada entre peso real e os pesos estimados e entre a determinação do índice de massa corporal. Conclusão: Os pesos obtidos pelas equações preditivas em comparação ao peso real são de excelente concordância e baixa variabilidade, o mesmo encontrado quando determinado o índice de massa corporal, o que indica o uso de ambas as equações, como alternativa, quando a medida real não for possível.

Palavras-chave: Peso Corporal. Índice de Massa Corporal. Técnicas de Estimativa. Pacientes Internados.

\section{Introduction}

Anthropometric measurements may be sensitive indicators of health, development and growth. Between them, body weight is a simple measure, which is the sum of all body compartments. ${ }^{1}$

However, in clinical practice, these measures cannot always be determined in a conventional manner, because of factors such as bed rest, difficulty in remaining in a standing position, lack of special equipment for measurement in bed and the type of morbidity that affects a patient, among 
other factors. ${ }^{2,3}$ Methods for weight estimation (e.g., predictive equations) have been proposed, enabling the nutritional assessment of these patients. ${ }^{4-6}$

The first prediction equations for weight measurement were proposed by Chumlea et al. ${ }^{6}$ and were derived from studies conducted in a North American, white, elderly population. They are based on measures of arm circumference, calf circumference and subscapular skinfold. ${ }^{1}$

In Brazil, equations for weight estimation were proposed by Rabito et al. in $2006^{4}$ and validated in $2008^{5}$ from studies conducted in two Brazilian hospitals with adults and the elderly. The equation is based on the circumference of the abdomen, the arm and the calf.

Although the application of these equations enables the estimation of weight data, it does not take into account variations resulting from different ages, nationalities and races, which can compromise the accuracy of the results by underestimating or overestimating the actual measurements. Thus, as body weight is used not only to identify nutritional risk and diet therapy planning but also for clinical care, ${ }^{7}$ one has to make sure that the use of these equations produces results that agree with the real measurements because they have been validated and are widely applied in different health conditions, stages of life and ethnicities.

The objective of this study was to evaluate the correlation between predictive equations for body weight estimation and their use in determining body mass index in hospitalized men and women.

\section{Methods}

Study Design

This was a descriptive study with a cross-sectional design, conducted in Vitória/Espirito Santo (ES), Brazil, from July 2014 to November 2015, in the General Surgery and Reconstructive Unit of a university hospital.

All patients admitted to the above-mentioned unit were evaluated if they met the following inclusion criteria: adult (20 to 59.9 years) or elderly ( $\geq 60$ years); hemodynamic stability; possibility of undertaking the nutritional assessment within 48 hours of hospital admission. Exclusion criteria were: being on contact precaution; being bedridden; or presence of edema or ascites.

The present study is part of a research project entitled "Malnutrition and associated factors in a university hospital in Grande Vitoria (ES)", approved by the Ethics Committee on Human Research of Federal University of Espírito Santo (CAAE: 27954014.0.0000.5060). All participants signed a consent form. 


\section{Data Collection}

The nutritional assessment was made by the measurement of weight, height, both considered the gold standard in this study, and the measurements required for the calculation of the predictive equations: arm circumference (AC), waist circumference (WC), calf circumference (CC), knee height $(\mathrm{KH})$ and subscapular skinfold thickness (SST).

Measurements of weight and height were performed according to the techniques proposed by Lohman et al. ${ }^{8}$ Circumferences were measured according to the techniques of Callaway et al. ${ }^{9}$ by using flexible, inelastic tape on the non-dominant side of the body.

Knee height was measured with individuals sitting down, forming a 90-degree angle with their knee and ankle ${ }^{10}$. Subscapular skinfold thickness was calculated in the non-dominant hand by the average of three measurements performed obliquely on the longitudinal axis, following the direction of the ribs, located one centimeter below the inferior angle of the scapula. ${ }^{11}$

The equations of Chumlea et al. ${ }^{6}$ and Rabito et al. ${ }^{4}$ were used for weight estimation (Table 1).

Table 1. Formulas used for the estimation of body weight.

\begin{tabular}{ll}
\hline & \multicolumn{1}{c}{ Weight $(\mathrm{kg})$} \\
\hline Chumlea et al.. 1988 & Women: $[1.27 \times \mathrm{xC}(\mathrm{cm})]+[0.87 \times \mathrm{KH}(\mathrm{cm})]+[0.98 \times \mathrm{AC}$ \\
& $(\mathrm{cm})]+[0.4 \times \mathrm{SSST}(\mathrm{cm})]-62.35$ \\
& Men: $[0.98 \times \mathrm{CC}(\mathrm{cm})]+[1.16 \times \mathrm{KH}(\mathrm{cm})]+[1.73 \times \mathrm{AC}(\mathrm{cm})]+$ \\
& {$[0.37 \times \mathrm{SSST}(\mathrm{mm})]-81.69$} \\
\hline Rabito et al.. 2006 & Equation III: $[0.5759 \times \mathrm{AC}(\mathrm{cm})]+[0.5263 \times \mathrm{WC}(\mathrm{cm})]+$ \\
& {$[1.2452 \times \mathrm{CC}(\mathrm{cm})]-[4.8689 \times(\mathrm{sex}) * 3-32.9241$} \\
\hline
\end{tabular}

The choice of the Rabito et al. 2006 equation $^{4}$ was due to the recommendation of the authors after the validation process. ${ }^{5}$

To facilitate the presentation of the data, actual weight was represented in the tables by letter "A". Letter "C" represented weight determined with the equation by Chumlea et al. ${ }^{6}$ and letter "R" represented weight as determined by Rabito et al. ${ }^{4}$

Body mass index (BMI) was calculated with the equation: weight $(\mathrm{kg}) / \mathrm{height}\left(\mathrm{m}^{2}\right)$. This was used to calculate BMI, actual weight (A) (BMI A), weight estimated by Chumlea et al. ${ }^{6}$ (C) (C BMI) and weight estimated by Rabito et al. ${ }^{4}$ (R) (R BMI).

The researchers involved in the data collection were previously trained through a pilot project in order to standardize the procedures and techniques in use. 


\section{Statistical analysis}

Data were analyzed using the SPSS software version 21.0. Percentages were used to describe continuous variables, mean and standard deviation, and categorical variables. Data normality was assessed using the Kolmogorov-Smirnov test. All variables were normally distributed. To evaluate the correlation between actual and estimated measurements, a graphical presentation of the Bland-Altman method, ${ }^{12,13}$ was designed to measure bias, the dispersion of the points around the mean and possible outliers and trends. This analysis enabled the calculation of Student's $t$ test and the linear regression coefficient. Student's t test was used to assess the mean difference between actual weight and estimated weight. The linear regression coefficient was considered as a dependent variable.The difference between it and estimated weight was estimated to obtain the coefficient. The intraclass correlation coefficient (ICC) was applied to evaluate the degree of agreement between the actual and the estimated measures. The interpretation of the ICC was based on the proposal by Bland and Altman, ${ }^{14}$ and the amounts considered were: $<0.4$ unacceptable; 0.41 to 0.6 good reproducibility; 0.61 to 0.80 very good reproducibility and 0.81 to 1.0 excellent reproducibility. For all comparisons, the significance level adopted was 0.05 .

\section{Results}

During the study period, 427 patients of both sexes were evaluated. Of these, 120 patients were excluded because the measurement of one or more measures employed in the predictive equations proposed was not possible. Of the 307 patients evaluated, 208 (67.8\%) were adults and 99 (32.2\%) were elderly, mean age $51.71 \pm 16.38$ years. Regarding gender, 139 (45.3\%) were females and 168 $(54.7 \%)$ were males. Table 2 shows other variables characterizing the sample.

Table 2. Sample characteristics and variables used for the predictive equations of weight in hospitalized men and women. Vitória-ES, 2015.

\begin{tabular}{lccc}
\hline Variables $(\mathrm{n}=307)$ & Mean & DP & Min - Max \\
\hline Age $($ years $)$ & 51.71 & 16.38 & $20.0-87.0$ \\
BMI A $\left(\mathrm{kg} / \mathrm{m}^{2}\right)$ & 24.54 & 4.59 & $13.02-39.04$ \\
WC $(\mathrm{cm})$ & 90.41 & 10.52 & $61.5-125.0$ \\
KH $(\mathrm{cm})$ & 50.38 & 3.60 & $41.6-58.0$ \\
CC $(\mathrm{cm})$ & 34.91 & 3.99 & $22.2-46.0$ \\
AC $(\mathrm{cm})$ & 28.96 & 4.14 & $16.0-40.0$ \\
SST $(\mathrm{mm})$ & 18.86 & 7.32 & $4.50-43.0$ \\
\hline
\end{tabular}


Table 3 shows the results of the different concordance analyses for body weight. Regarding body weight, the assessment of agreement by Student's t, obtained from the Bland Altman analysis, showed no significant difference between the differences of actual weight and estimated weight by using the two equations in men. Differences in women were found between actual weight and estimated weight using the equation by Chumlea et al. $(p=0.00)$.

The linear regression coefficient found between actual weight and weight estimated by Rabito et al. was $0.44(\mathrm{p}=0.00)$ in men and $0.18(\mathrm{p}=0.03)$ in women. There may be a slight increase in weight, in both groups, when using the equation of Rabito et al., which did not occur when using the equation by Chumlea et al.

The agreement was assessed by the intraclass correlation coefficient; excellent reproducibility was obtained (ICC> 0.90) between men and women for both predictive equations.

Table 3. Comparison between actual weight and weight estimated by Chumlea et al. and Rabito et al. in hospitalized men and women.Vitoria-ES, 2015.

\begin{tabular}{|c|c|c|c|c|c|c|c|}
\hline $\begin{array}{c}\text { Variable } \\
(307)\end{array}$ & Mean & SD & $\begin{array}{c}\text { Student's } \\
\mathrm{T}^{\mathrm{a}}\end{array}$ & $\begin{array}{c}\text { Linear } \\
\text { regression } \\
\text { coefficient }^{\mathrm{a}}\end{array}$ & $\begin{array}{c}p \text { value Linear } \\
\text { regression } \\
\text { coefficient }^{\mathrm{a}}\end{array}$ & $\mathrm{ICC}^{\mathrm{b}}$ & $\begin{array}{c}p \text { value } \\
\text { ICC }^{\mathrm{b}}\end{array}$ \\
\hline \multicolumn{8}{|l|}{ Men (168) } \\
\hline Weigth A (kg) & 69.94 & 14.03 & & & & & \\
\hline Weigth C (kg) & 69.10 & 13.20 & 0.06 & 0.15 & 0.06 & 0.95 & $0.00 *$ \\
\hline Weigth R (kg) & 69.90 & 11.67 & 0.93 & 0.44 & $0.00 *$ & 0.95 & $0.00 *$ \\
\hline \multicolumn{8}{|l|}{ Women (139) } \\
\hline Weigth A (kg) & 63.67 & 13.09 & & & & & \\
\hline Weigth C (kg) & 60.93 & 12.48 & $0.00 *$ & 0.13 & 0.12 & 0.95 & $0.00 *$ \\
\hline Weigth R (kg) & 64.82 & 12.11 & 0.16 & 0.18 & $0.03 *$ & 0.92 & $0.00 *$ \\
\hline
\end{tabular}

Table 4 shows the results of the different concordance analyses for BMI. In assessing actual BMI and BMI using the estimated weights by Student's t, there were no significant differences between actual BMI and estimated BMI when using both equations in men. Contrary results were found among women. There was a significant difference between actual BMI and BMI determined from the estimated weights using both equations $(p=0.00)$ in women. 
The regression coefficient obtained between actual BMI and BMI calculated from weight estimated by Rabito et al. in women was 0.19 ( $p=0.02)$. The difference may be higher in this classification when using the weight obtained by Rabito et al. The intraclass correlation coefficient between BMI showed excellent reproducibility (ICC> 0.90) between men and women, regardless of the estimated weight used for its determination.

Table 4. Comparison between actual body mass index and body mass index estimated by Chumlea et al. and Rabito et al. in hospitalized men and women.Vitória-ES, 2015.

\begin{tabular}{|c|c|c|c|c|c|c|c|}
\hline $\begin{array}{c}\text { Variable } \\
\text { (307) }\end{array}$ & Mean & SD & $\begin{array}{c}\text { Student's } \\
\mathrm{T}^{\mathrm{a}}\end{array}$ & $\begin{array}{c}\text { Linear } \\
\text { regression } \\
\text { coefficient }{ }^{\mathrm{a}}\end{array}$ & $\begin{array}{c}p \text { value Linear } \\
\text { regression } \\
\text { coefficient }^{\mathrm{a}}\end{array}$ & $\mathrm{ICC}^{\mathrm{b}}$ & $\begin{array}{c}p \text { value } \\
\text { ICC }^{\mathrm{b}}\end{array}$ \\
\hline \multicolumn{8}{|l|}{ Men (168) } \\
\hline BMI A $\left(\mathrm{kg} / \mathrm{m}^{2}\right)$ & 24.34 & 4.19 & & & & & \\
\hline BMI C $\left(\mathrm{kg} / \mathrm{m}^{2}\right)$ & 24.06 & 3.99 & 0.08 & 0.10 & 0.19 & 0.93 & $0.00 *$ \\
\hline BMI R $\left(\mathrm{kg} / \mathrm{m}^{2}\right)$ & 24.41 & 3.81 & 0.62 & 0.20 & 0.08 & 0.94 & $0.00^{*}$ \\
\hline \multicolumn{8}{|l|}{ Women (139) } \\
\hline BMI A $\left(\mathrm{kg} / \mathrm{m}^{2}\right)$ & 25.62 & 4.95 & & & & & \\
\hline BMI C $\left(\mathrm{kg} / \mathrm{m}^{2}\right)$ & 24.58 & 4.99 & $0.00 *$ & -0.02 & 0.78 & 0.95 & $0.00 *$ \\
\hline BMI R $\left(\mathrm{kg} / \mathrm{m}^{2}\right)$ & 26.33 & 5.34 & $0.00 *$ & 0.19 & $0.02 *$ & 0.95 & $0.00 *$ \\
\hline
\end{tabular}

Figure 1 shows the Bland-Altman limits of agreement between actual weight and estimated values according to sex. For both equations ( $\mathrm{C}$ and $\mathrm{R}$ ), there are average differences near to zero relative to actual weight, with good agreement for both sexes, since the plotted points are located between the extreme limits of agreement ( \pm 2 standard deviations of difference).

For men, the results show good agreement between measurements. The dispersion around the mean bias follows a random pattern and seems more homogeneous in this group, with the difference between the values $\mathrm{C}$ and $\mathrm{R}$ equations being near zero, with a bias of 0.84 and 0.03 $\mathrm{kg}$, respectively.

Among women, there was less agreement between the measurements. There was a tendency to overestimate weight compared to weight estimated by equation $\mathrm{C}(2.73 \mathrm{~kg})$ and there was slight weight underestimation when compared with weight estimated by equation $\mathrm{R}(-1.15 \mathrm{~kg})$. 


\section{Men (168)}

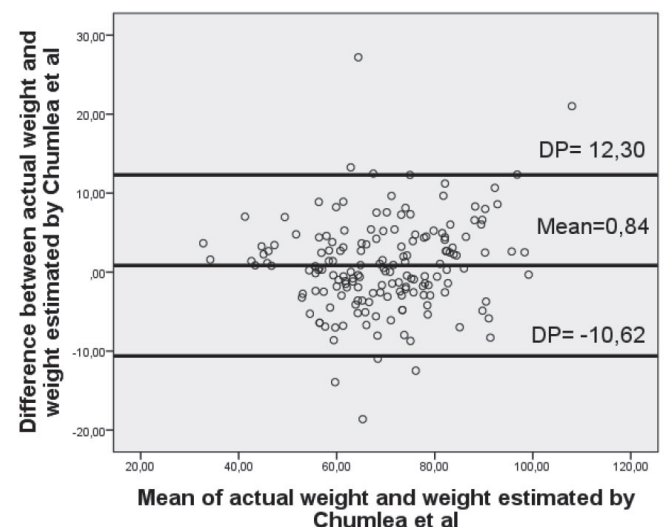

\section{Women (139)}

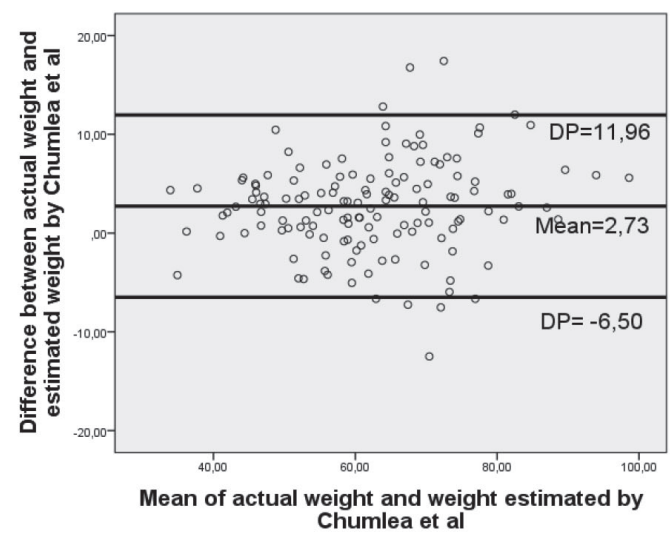

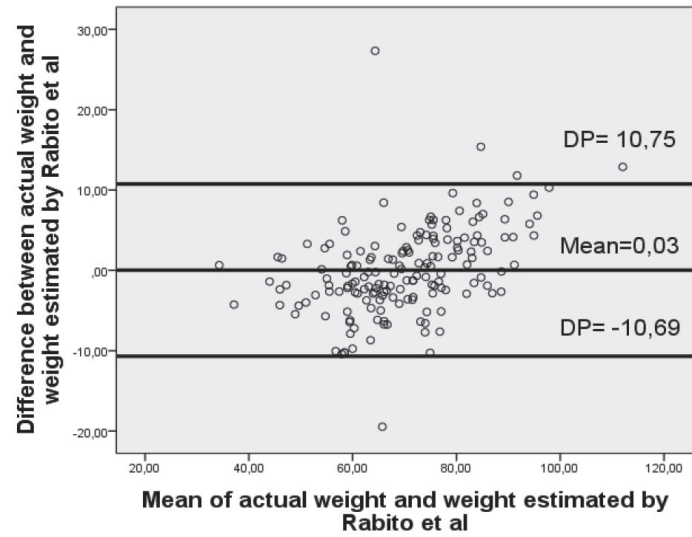

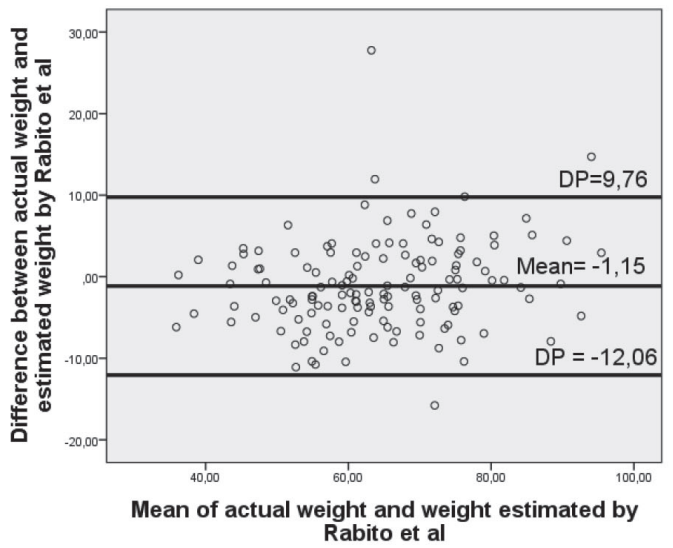

Figure 1. Bland-Altman agreement limits between actual weight $(\mathrm{kg})$ and estimated $(\mathrm{kg})$ values in hospitalized patients according to sex.

In addition to the graphical display of Bland-Altman, Figure 2 shows the classification of BMI, BMI C and BMI R. Among men, the results showed good agreement with the dispersion of differences around the bias value near zero.

As for women, although there was a greater dispersion of the differences between the measures, most of the plotted points are located between the limits of agreement with the biases of mean justaway from zero. 


\section{Men (168)}
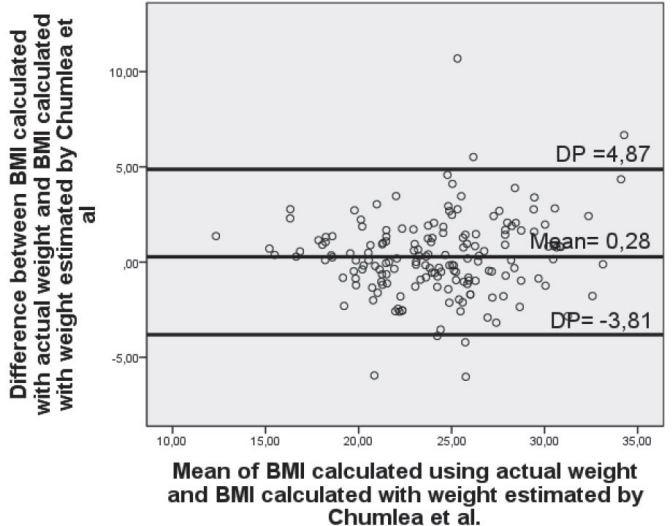

Women (139)
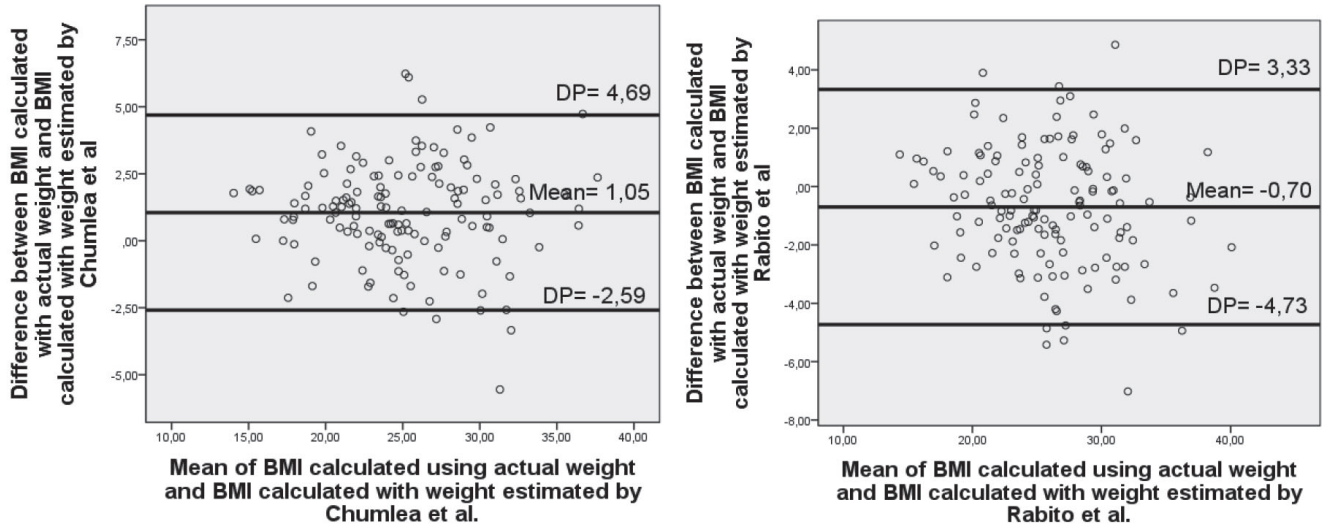

Figure 2. Bland-Altman agreement limits between actual BMI $\left(\mathrm{kg} / \mathrm{m}^{2}\right)$ and estimated $(\mathrm{kg} /$ $\mathrm{m}^{2}$ ) values in hospitalized patients according to sex.

\section{Discussion}

The results of this study indicate that the use of the equations proposed by Chumlea et al. ${ }^{6}$ and Rabito et al. ${ }^{4}$ generated weight estimates that were associated with actual measurements. There was good agreement between the equations proposed in this study, with little variability between the results obtained, either for body or BMI weight. The Bland-Altman analysis corroborated these findings, showing a slight bias between the mean differences, which results in changes of little clinical relevance. 
The determination of a safe nutritional diagnosis from body measurements and BMI ensures that the nutritional and clinical care are more effective and are tailored to the needs of patients and, in many cases, these variables can only be obtained from estimated measures. Values provided by the patient or family or visual measurements are unreliable. ${ }^{15}$

The specifics of the anthropometric variables that make up the equations, additional limitations of hospitalized individuals, such as immobility, presence of edema of upper and lower limbs, ascites, require two evaluators in some measurements; in addition, the accuracy of these evaluators are determining factors in the agreement between equations. ${ }^{16}$

Similar studies with hospitalized adults ${ }^{17}$ and elderly subjects ${ }^{18}$ found no statistical similarity between the actual measured weights and the estimates by Chumlea et al. and Rabito et al. Different results were found in a study with hospitalized adults, in which average weights estimated with the equation by the Chumlea et al. were similar to actual weight. ${ }^{7}$

In elderly Mexicans, the equation by Rabito et al. showed satisfactory agreement between actual and estimated measures, thus the Brazilian equation be an efficient and easy alternative when real measurement is impossible. ${ }^{17}$

The use of these equations for nutritional diagnosis using estimated weight is still controversial in some studies. ${ }^{7,17,19,20}$ However, these studies have different populations and methods of analysis, hence comparisons and discussions are difficult to be made. Our findings showed that the BMI measurements obtained from the predicted weights were significantly concordant with actual BMI, and did not interfere in the nutritional diagnosis.

Regarding the choice of the equation, it is worth considering the individual differences, taking into account stage of life, gender, ethnicity, health status and functional capacity, as well as the equipment available, the field of measurement techniques of variables used in equations and the limitations of each one of them.

This study has some limitations, such as the cross-sectional design, the characteristics of the ward where the study took place and the clinical condition of the patients. However, a positive feature was the collection and analysis of insightful data by researchers.

\section{Conclusion}

The results show that the weights obtained by predictive equations compared to actual weight show excellent agreement and low variability. The same is true for BMI. Although other criteria should be used in their applications, the equations being studied may be used as an alternative when real measurement is impossible, especially in hospital settings, because of the limitations 
found in this population. These equations are practical and affordable tools. Their low cost and easy implementation in clinical practice make them important for planning dietotherapeutic intervention and for clinical care in the absence of actual measurements.

\section{Acknowledgments}

We are particularly thankful to the University Hospital Cassiano Antônio Moraes for all support and assistance provided throughout the research.

\section{Contributors}

Leal LP and Mognhol MS participated in data collection and manuscript writing. Silva NMF and Petarli GB, participated in study design, data collection and manuscript writing. Nunes PMF participated in the revision of the final manuscript. Guandalini VR coordinated study design, data analysis, manuscript writing and revised the final manuscript.

Conflict of Interest: The authors declare no conflict of interest.

The present study is part of a research project entitled "Malnutrition and associated factors in a university hospital of Grande Vitoria (ES)", approved by the Ethics Committee on Human Research of Federal University of Espirito Santo (CAAE: 27954014.0.0000.5060). All participants signed a consent form.

\section{References}

1. Fidelix MSP, organizadora. Manual orientativo: sistematização do cuidado de nutrição. São Paulo: Associação Brasileira de Nutrição; 2014. 66 p.

2. Barceló M, Torres O, Mascaró J, Francia E, Cardona D, Ruiz D. Assessing nutritional status in the elderly; evaluation of Chumlea's equations for weight. Nutr Hosp. 2013; 28(2):314-318.

3. Darnis S, Fareau N, Corallo CE, Poole S, Dooley MJ, Cheng AC. Estimation of body weight in hospitalized patients. Q J Med. 2012; 105:769-774.

4. Rabito EI, Vannucchi GB, Suen VMM, Castilho Neto LL, Marchini JS. Weight and height prediction of immobilized patients. Rev Nutr. 2006; 19(6):655-61.

5. Rabito EI, Mialich MS, Martinez EZ, Garcia RWD, Jordão AA, Marchini JS. Validation of predictive equations for weight and using a metric tape. Nutr Hosp. 2008; 23(6):614-18.

6. Chumlea WMC, Guo SS, Roche AF, Steinbaugh ML. Prediction of body weight for the non-ambulatory elderly from anthropometry. J Am Diet Assoc. 1988; 88(5):564-87. 
7. Dock-Nascimento DB, Aguilar-Nascimento JE, Costa HCBAL, Vale HV, Gava MM. Precision of estimated body weight and height for nutritional assessment in patients with cancer. Rev Bras Nutr Clin. 2006; 21(2):111-6.

8. Lohman TG, Roche AF, Martorell R. Anthropometric standardization reference manual. $15^{\mathrm{a}}$ ed. Ohio: Human Kinetics; 1988.

9. Callaway CW, Chumlea WMC, Bouchard C, Himes JH, Lohman TG, Martin AD, et al. Circunferences. In: Lohman TG, Roche AF, Martorell R, editors. Anthropometric standardization reference manual. $15^{\mathrm{a}}$ ed. Ohio: Human Kinetics; 1988. p. 39-54.

10. Chumlea WC, Roche AF, Steinbaugh ML. Estimating stature from knee height for persons 60 to 90 years of age. J Am Geriatr Soc. 1985; 33(2):116-20.

11. Durnin JVGA, Womersley J. Body fat assessed from total body density and its estimation from skinfold thickness: measurements on 481 men and women aged from 16 to 72 years. Br J Nutr. 1974; 32(1):77-97.

12. Altman DG, Bland JM. Measurement in Medicine: The analysis of method comparison studies. The Statistician 1983; 32(3):307-17.

13. Bland JM, Altman DG. Measuring agreement in method comparison studies. Stat Methods Med Res. 1999; 8(2):135-60.

14. Bland JM, Altman DG. A note on the use of the intraclass correlation coefficient in the evaluation of agreement between two methods of measurement. Comput Biol Med. 1990; 20(5):337-40.

15. Osuna-Padilla IA, Borja-Magno AI, Leal-Escobar G, Verdugo-Hernández S. Validation of predictive equations for weight and height using body circumferences in mexicanelderlys. Nutr Hosp. 2015; 32(6):2898-902.

16. Santos EA, Camargo RN, Paulo AZ. Comparative analysis of equations for estimating weight and height for hospitalized patients. Rev Bras Nutr Clin. 2012; 27(4):218-25.

17. Melo APF, Salles RKS, Vieira FGK, Ferreira MG. Methods for estimating body weight and height in hospitalized adults: a comparative analysis. Rev Bras Cineantropom Desempenho Hum. 2014; 16(4):475-484.

18. Souza R, Fraga JS, Gottschall CBA, Busnello FM, Rabito E. Avaliação antropométrica em idosos: estimativas de peso e altura e concordância entre classificações de IMC. Rev Bras Geriatr Gerontol. 2013; 16(1):81-90.

19. Rezende FAC, Rosado LEFPL, Franceschinni SCC, Rosado GP, Ribeiro RCL. Assessment of equations that estimate weight and height in adult men. Rev Nutr. 2009; 22(4):443-51.

20. Balode A, Stolarova A, Villerusa A, Zepa D, Kalnins I, Vētra J. Estimation of body weight and stature in latvian hospitalized seniors. Papers on Anthropology 2015; XXIV(2):27-36

Received: , August 17, 2016

Reviewed: September 18, 2016

Accepted: November 21, 2016 